\title{
Currency Crises and Foreign Credit in Emerging Markets: Credit Crunch or Demand Effect?
}

\author{
Galina Hale \\ Federal Reserve Bank of San Francisco \\ Carlos Arteta \\ Board of Governors of the Federal Reserve System
}

January 2007

Working Paper 2007-02

http://www.frbsf.org/publications/economics/papers/2007/wp07-02bk.pdf

The views in this paper are solely the responsibility of the authors and should not be interpreted as reflecting the views of the Federal Reserve Bank of San Francisco or the Board of Governors of the Federal Reserve System. 


\title{
Currency Crises and Foreign Credit in Emerging Markets: Credit Crunch or Demand Effect?
}

\author{
Galina Hale* \\ Federal Reserve Bank of San Francisco \\ Carlos Arteta \\ Board of Governors of the Federal Reserve System
}

January 2007

\begin{abstract}
Currency crises of the past decade highlighted the importance of balance-sheet effects of currency crises. In credit-constrained markets such effects may lead to further declines in credit. Controlling for a host of fundamentals, we find a systematic decline in foreign credit to emerging market private firms of about $25 \%$ in the first year following currency crises, which we define as large changes in real value of the currency. This decline is especially large in the first five months, lessens in the second year and disappears entirely by the third year. We identify the effects of currency crises on the demand and supply of credit and find that the decline in the supply of credit is persistent and contributes to about $8 \%$ decline in credit for the first two years, while the $35 \%$ decline in demand lasts only five months.
\end{abstract}

JEL classification: F34, F32, G32

Key words: currency crises, credit rationing, balance-sheet effects, credit constraints, original sin

${ }^{*}$ Corresponding author. Contact: Federal Reserve Bank of San Francisco, 101 Market st., MS1130, San Francisco, CA 94105. galina.b.hale@sf.frb.org. We are grateful to Emily Breza, Chris Candelaria, Rachel Carter, Yvonne Chen, and Damian Rozo for outstanding research assistance. Anusha Chari, Pierre-Olivier Gourinchas, Jose Scheinkman, Martin Schneider, and the participants of the seminar at UC Berkeley and SCCIE conference on "Firms in Emerging Markets" provided most helpful comments. All errors are ours. The views in this paper are solely the responsibility of the authors and should not be interpreted as reflecting the views of the Board of Governors of the Federal Reserve System or any other person associated with the Federal Reserve System. 


\section{Introduction}

Emerging market currency crises of the late 1990s were generally accompanied by a substantial decline in economic activity in affected countries (Gupta, Mishra, and Sahay, 2003; Hutchison and Noy, 2002). Much of the literature attributes a large part of this decline to currency-related balance-sheet problems that arise when firms that have borrowed in foreign currency find their net worth falling after a large depreciation of domestic currency. The literature has shown that these balance-sheet effects can lead to a contraction in investment 11 popular view seems to be that this decline in investment is driven by a credit crunch; indeed, Calvo, Izquierdo, and Talvi (2006) show that the recovery from financial crises tends to take place without a recovery in credit.

While the reduction in credit following currency crises is frequently discussed, the empirical analysis of this phenomenon is scarce. Desai, Foley, and Forbes (forthcoming) show that after a currency crisis, domestic firms suffer from decline in credit, while multinationals expand their activity. Blalock, Gertler, and Levine (2004) present evidence consistent with21 the credit crunch after the 1998 crisis in Indonesia. We contribute to this literature by systematically analyzing the effects of currency crises in the past 25 years on credit provided to emerging markets' domestic private firms by foreign creditors.2 In addition to documenting the qualitative decline in foreign credit to emerging markets' private sector, which represents over $30 \%$ of total foreign credit to emerging markets $3^{3}$ we provide quantitative analysis of the size and the duration of this decline.

Documenting the decline in credit, however, is not the same as identifying a credit crunch. A credit crunch implies that firms are interested in obtaining loans but are unable to do so, that is, the decline in credit due to a contraction in credit supply. Nevertheless, some of the decline in credit could be due to a reduction in firms' demand for capital. To our knowledge, there is no systematic evidence on the effects of currency crises on the demand and supply of foreign credit to

\footnotetext{
${ }^{1}$ Aghion, Bacchetta, and Banerjee (2001), Aghion, Bacchetta, and Banerjee (2004), Cespedes, Chang, and Velasco (2003).

${ }^{2}$ We focus on emerging markets because the exchange rate movements appear to be more destabilizing in developing countries than in industrial countries (Shaghil, Gust, Kamin, and Huntley, 2002). We have no access to firm-level data on domestic lending; however, we include foreign borrowing by financial sector in our study, thus analyzing total availability of foreign capital to the country's private sector.

${ }^{3}$ See, for example, Chapter 4 of the Global Development Finance, The World Bank, 2005. According to Chapter 4 of the Global Financial Stability Report, IMF, April 2005, about 25\% of emerging markets' corporate bonds and bank credit are external, and this number is much larger for Latin American emerging economies.
} 
emerging-market private firms. This paper provides such an analysis.

The "original sin" literature argues that most emerging market borrowers cannot borrow abroad in their own currency 4 as a result, they may accumulate large foreign-currency liabilities. If the asset side of these borrowers' balance sheets is denominated primarily in local currency, a large depreciation of the local currency leads to a large reduction in a company's net worth and potentially to solvency problems. Thus, according to the standard credit rationing argument (Stiglitz and Weiss, 1981; Calomiris and Hubbard, 1990; Mason, 1998), it is natural to expect that foreign lenders would reduce the supply of credit to these borrowers. This would lead to a financial accelerator effect (Bernanke and Gertler, 1989) and deepen the economic downturn after a currency crisis.

There are reasons to believe that firms will also lower their demand for credit in general and for foreign credit in particular. First, the decline in aggregate demand that accompanies currency crises would increase firms' inventories and reduce their demand for credit. This decline in aggregate demand will mostly affect the firms that sell their products domestically. Exporting firms, on the other hand, will experience an increase in their foreign currency revenues relative to their operating costs, which are denominated mostly in domestic currency 5 Thus, their earnings will go up and they may be inclined to demand less credit. Finally, firms might decide to reduce the currency mismatch on their balance sheets and increase their borrowing in domestic currency. Since they are unable to do that on foreign capital markets, they will increase their demand for domestic funds and reduce their demand for foreign credit 6

Using firm-level data on foreign bond issuance and foreign syndicated bank loan contracts for 29 emerging markets between 1981 and 2004, we calculate the total amount of new credit that private, domestically-owned firms obtained on the bond market or from bank syndicates in each month $]^{7}$ We then analyze how this aggregate measure of credit is affected by currency crises, which we define as large drops in real value of the currency. We do not restrict our analysis to the cases of currency

\footnotetext{
${ }^{4}$ This point was first raised by Eichengreen and Hausmann (1999).

${ }^{5}$ In fact, Bris and Koskinen (2002) in their model show that this effect could be a reason for competitive devaluations.

${ }^{6}$ This last effect, however, is likely to be neutralized by the increased demand for foreign credit by domestic financial firms.

${ }^{7}$ We exclude from our analysis all the firms that are foreign-owned and all the firms that are owned by central or local governments, which we would not be able to do with aggregate data.
} 
devaluations and collapses of the fixed exchange rate regimes, because large currency depreciations under floating exchange rate regimes may have similar effects 8 We define currency crisis episodes based on real, rather than nominal, depreciation to prevent hyperinflation periods from dominating the sample $\sqrt[9]{9}$

We construct a number of indicators that describe various aspects of each country's economy as well as factors that affect the world supply of capital to emerging markets, which we use as control variables. Since foreign credit to the country could be conditional on the country having an agreement with the IMF, we include this indicator in our list of control variables. In addition, we control for banking crises (Hutchison and Noy, 2005) and for debt crises (Arteta and Hale, 2006).

Using fixed-effect panel data regressions, we find, not surprisingly, that there is a significant decline in credit to emerging market firms (measured either in U.S. dollars or in local currency) in the aftermath of currency crises. We find that foreign credit to the private sector falls by over $30 \%$ compared to the country mean in the first two years after a currency crisis and then recovers. About a third of this decline in credit in the first year and about half of the decline in the second year are explained by the worsening of macroeconomic fundamentals and other control variables. We find that the decline in credit is most severe during the first five months after the crisis and that there is little or no evidence of a decline in credit prior to the currency crisis.

By separating demand factors from supply factors and using a proxy for the price of credit, we are able to identify whether the decline in credit that we document comes from the demand or the supply side. Because we do not have good exclusion restrictions for the supply equation, we assume that supply of credit for each firm is perfectly elastic at a given price. Thus, our supply equation is simply the price equation. We then estimate the demand equation without imposing restrictions on its slope with respect to our measure of price.

At first it appears that both demand and supply contribute equally to the decline in credit. However, once we control for sovereign debt crises (Arteta and Hale, 2006), we find that the decline in demand for credit (which is large at 30\%) only persists for five months, while the initial decline in the market

\footnotetext{
${ }^{8}$ We analyze separately devaluations and collapses of the pegs in our robustness tests and find that the effects of this sub-sample of our events are larger than for the full sample, as one would expect.

${ }^{9}$ Using nominal depreciation leads to only minor changes in our set of currency crises and does not change our results.
} 
value of bonds of over $20 \%$ recovers very gradually and is still statistically significant and equal to over $10 \%$ in the second year after the crisis. Given our estimate of the price elasticity of demand, this decline in the market value of bonds translates to about $8 \%$ decline in credit initially and about $5 \%$ decline in credit in the second year. These results square well with our findings for the reduced form - the initial large decline in credit is due to a reduction in both demand and supply, while the persistent decline is due to the contraction in supply only.

We estimate a number of additional regressions as extensions and robustness tests and find that the above results are robust to the definition of dependent variable and the currency crisis indicator, econometric model specification, sample, and the set of control variables.

To summarize, we find systematic evidence of a foreign credit crunch that is substantial and persistent in the aftermath of currency crises. This foreign credit crunch is important as it extends to the entire private sector of the economy, thus limiting the overall credit availability in the country. In this way, our findings are consistent with the evidence presented in Desai, Foley, and Forbes (forthcoming) and Blalock, Gertler, and Levine (2004). While we do find an even larger decline in demand for foreign credit, it only lasts for about five months after the crisis and therefore does not contribute much to the creditless recovery phenomenon described in Calvo, Izquierdo, and Talvi (2006).

The remainder of the paper is organized as follows. Part two describes the empirical approach of the paper and the data. Part three presents the results of the empirical analysis. Part four concludes.

\section{Empirical approach and data sources}

We begin by analyzing the reduced-form specification, which excludes the cost of credit. As we will discuss later, estimating demand and supply effects requires a proxy for the cost of credit, which unfortunately limits our sample size. Using a longer sample period, as we do in the first part of our analysis, allows us to estimate the size and the persistence of the decline in foreign credit to the private sector more precisely. 


\subsection{Reduced form specification}

To test for a decline in credit in the aftermath of a currency crisis, we estimate the following reduced-form equation:

$$
q_{i t}=\alpha_{i}+\alpha_{t}+\beta_{0} d_{i t}+\sum_{\tau=1}^{K} \gamma_{\tau} z_{\tau i t}+\mathbf{X}_{\mathbf{i t}}^{\prime} \eta+\varepsilon_{i t},
$$

where $q_{i t}$ is a measure of credit, $\alpha_{i}$ is a set of country fixed effects absorbing the effect of initial conditions, $\alpha_{t}$ is a set of year fixed effects absorbing the effect of a common trend, $d_{i t}$ is an indicator of a currency crisis month, $z_{\tau i t}$ is an indicator that the currency crisis occurred more than $\tau-1$ but less than $\tau$ years ago (we set $K=3$ ), $\mathbf{X}_{\mathbf{i t}}$ is a set of all control variables, and $\varepsilon_{i t}$ is a set of robust errors clustered on country. Specific definitions of all these variables are below. Data sources are described in detail in the Appendix.

We estimate the above equation by ordinary least squares. In addition, to test for the robustness of our results to the empirical specification, we allow for autocorrelation in errors; we include a lagged dependent variable on the right-hand side by itself and also interacted with country fixed effects; we estimate a two-sided Tobit model by maximum likelihood; we estimate the above equation country by country and obtain average $\beta$ coefficients. Some of these test results are reported below, and the rest are described along with other robustness tests in Section 3.3.

The above specification assumes that the decline in credit is constant throughout each year following a currency crisis. It is, however, reasonable to expect that, at least in the first year, the effect subsides gradually over time. In addition, there is a possibility that credit declines before the crisis strikes, either because the currency crisis is expected or because of the exogenous sudden stop in capital flows (Calvo, 1998); in the latter case, the sudden stop would lead to a decline in credit to the private sector and could also precipitate the currency crisis as foreign investors convert their local currency assets to U.S. Dollars or other "hard" currency.

To estimate whether there is a dampening of the effect in the first year after the currency crisis, we replace $z_{1 i t}$ with the $m_{\varsigma i t}$ in the above regression, where $m_{\varsigma i t}$ indicates that the currency crisis occurred exactly $\varsigma$ months ago. We include up to 11 months in the regressions, since further effects 
are captured by $z_{\tau i t}, \tau=2,3$. To test for the sudden stop effects and expectations of currency crises, we include 12 monthly leads in the regression as well.

\subsection{Estimating demand and supply}

We use a triangular identification technique identify demand and supply, i.e., we assume that the supply of credit for each country is perfectly elastic, due to competition between investors, and therefore does not depend on the amount borrowed. We believe that this assumption is more innocuous than any assumption we could make regarding exclusion restrictions from the supply equation. On the other hand, we consider variables that are not likely to affect the demand for credit but affect the supply of credit, as described below.

We estimate the following system using three-stage least squares for more robust estimates:

$$
\begin{gathered}
p_{i t}=\alpha_{i}+\beta_{0}^{s} d_{i t}+\sum_{\tau=1}^{K} \gamma_{\tau}^{s} z_{\tau i t}+\mathbf{X}_{\mathbf{i t}}^{\mathbf{d}^{\prime}} \eta^{\mathbf{s}}+\mathbf{X}_{\mathbf{i t}}^{\mathbf{s}^{\prime}} \kappa^{\mathbf{s}}+\varepsilon_{i t}^{s}, \\
q_{i t}=\alpha_{t}+\lambda p_{i t}+\beta_{0}^{d} d_{i t}+\sum_{\tau=1}^{K} \gamma_{\tau}^{d} z_{\tau i t}+\mathbf{X}_{\mathbf{i t}}^{\mathbf{d}^{\prime}} \eta^{\mathbf{d}}+\varepsilon_{i t}^{d}
\end{gathered}
$$

where $p_{i t}$ is a measure of the cost of credit, $X_{i t}^{s^{\prime}}$ is a set of control variables excluded from the demand (or amount) equation, and $X_{i t}^{d^{\prime}}$ is a set of controls that affects both demand and supply of credit.

We do not impose restrictions on $\lambda$ but rather test whether it has the correct sign and yields a downward-sloping demand.

\subsection{Definition of a currency crisis: $d_{i t}$}

For our exchange rate variable, we use JP Morgan's Real Broad Effective Exchange Rate (REER) series 10 As Krugman (2001) points out, small amounts of currency depreciation do not lead to changes in firms' behavior. We therefore focus on episodes of large depreciations, which we define as a monthly decline in the REER by over $10 \%$. We choose $10 \%$ as a starting point, because it

\footnotetext{
${ }^{10}$ Using real exchange rate rather than nominal reduces the weight of hyperinflation episodes in our sample.
} 
represents just over $1 \%$ of the country-month observations and is about three standard deviations over the mean change in the REER. ${ }^{11}$ Thus, our currency crisis episodes are rare ${ }^{12}$

Since some of the countries in our sample experienced prolonged periods of currency depreciation 13 we observe sequences of months in which our depreciation episode indicator takes a value of one. Since each of these sequences clearly represents one continuing currency crisis, we set our currency crisis indicator to be equal to one in the first of these months but not in subsequent months. We allow for this indicator to take on a value of one again only after three consecutive months of REER depreciation of less than 10\% 14 Table 1 lists all 63 currency crisis episodes that are defined in this way, as well as the countries in our sample for which currency crisis have not occurred between 1981 and 2004, according to our definition. As Table 1 shows, our definition captures most "major" financial crises.

For most of the paper, we do not distinguish between devaluations, collapses of fixed exchange rate regimes, and large depreciation events during floating exchange rate regimes. As we discuss in the robustness tests section, while devaluations tend to have larger effects than depreciations, our overall qualitative results are the same.

\subsection{A measure of credit: $q_{i t}$}

From Bondware and Loanware data sets, we gather all foreign bond issues and foreign syndicated loan contracts obtained by emerging market firms between January 1981 and August 2004 ${ }^{15}$ Importantly, these do not include trade credit.

For bonds issued through offshore centers, we trace the true nationality of the borrowers by the

\footnotetext{
${ }^{11}$ We do not use a standard deviations measure due to difficulties in estimating the variance of the exchange rates, which is not constant over time. We do not use the index proposed by Eichengreen, Rose, and Wyplosz (1996), because we are only interested in the effects of real exchange rate changes rather than in the effects of speculative attacks. In particular, we do not include cases of failed attacks. We do control for reserves and interest rates; however, they are not part of our crisis definition.

${ }^{12}$ We report the sensitivity of our results to both the choice of exchange rate data and the definition of the large depreciation in the robustness tests section.

${ }^{13}$ See Reinhart and Rogoff (2004) for the list of countries with periods of "free falling" currencies.

${ }^{14}$ Again, in the robustness tests section, we test whether our results are sensitive to this definition of the tranquil period window.

${ }^{15}$ See Hale (2007) for the detailed description of these data sets. Bond data start in March 1991, because bond markets for most emerging economies did not exist in the 1980s.
} 
location of their headquarters. We exclude all firms that are owned by the government or by multinational or foreign companies $\sqrt{16}$ Most international bonds and loans are denominated in some OECD country currency, therefore we first convert the amounts into U.S. dollars according to the average exchange rate in the issue month and then aggregate the amounts of bond issues and of loans for each country-month. We drop from our analysis countries for which the total amount of bonds and loans for both sectors was nonzero in fewer than 24 months out of 264 months in our data sample. This ensures that we have enough identifying observations for each country and leaves us with the 29 countries listed in Table 1.

We divide each amount by the U.S. consumer price index (CPI) to obtain the amount of credit for each country-month in real dollars. We then construct our dependent variables as a percentage deviation from the country-specific average for each of the sectors ${ }^{17}$ Alternatively, we convert the amounts to local currency using the average exchange rate vis-à-vis U.S. dollars in a month of issue, discount it by the local CPI, and then calculate percentage deviations from country-specific means. Due to the high frequency of currency crises in some countries, we do not exclude crisis periods from our means, which biases the means downward; therefore, the effects we find might be underestimating the effects of crises.

Importantly, our measure represents the fluctuations in the gross borrowing of the emerging market firms. We believe that this is a proper measure to analyze the access of these firms to credit. The net measure would represent times when a lot of credit is being repaid as times of low access to credit, which needs not be the case. Our robustness tests demonstrate that our results are robust to controlling for principal and interest repayments as well as using a measure of net borrowing on the left-hand side.

Figure 1 illustrates the dynamics of credit measured in U.S. dollars for the six major currency crises of the 1990s 18 We can see that foreign credit to the private sector fell sharply after crises in Korea, Russia, and Argentina. However, for the other three countries presented - Mexico, Brazil, and

\footnotetext{
${ }^{16}$ Desai, Foley, and Forbes (forthcoming) find that multinationals expand their activities and credit as a result of currency depreciation.

${ }^{17}$ We use percentage deviations from the country-specific sample means for all continuous variables. Differences in means are captured by country fixed effects, while common trends are captured by year fixed effects. We do not use percentage deviations from country-specific trnds, because removing trends may also remove the effects of crises.

${ }^{18}$ For detailed description of credit data and its composition, see Arteta and Hale (2006) and Hale (2007).
} 
Turkey — the decline is not as evident. Of course, currency crises are accompanied by a number of changes in the economy that can affect foreign credit to the private sector. We control for these changes in the regression analysis presented in the next part of the paper.

\subsection{Cost of credit: $p_{i t}$}

To estimate demand and supply equations separately, we need a measure of the cost of credit. Unfortunately, Loanware and Bondware do not provide sufficient information on the pricing of credit. They include spreads only for a small subset of loan contracts and bond issues and these spreads are only primary - there is no information on secondary market pricing of credit. In addition, the pricing of each individual loan or bond issue might be driven by specific characteristics of the firms borrowing in a particular month. Since these characteristics are not available, pricing information obtained by aggregating primary spreads will be affected by the composition of the firms that borrowed in a particular month and therefore will be noisy.

Secondary price data are available only for a small subset of the bonds and are also quite sparse. For this reason, we resort to the JP Morgan country-specific EMBI Global Market Values Index that combines spreads on private and sovereign foreign bonds. For cases when a country-specific index is not available, we use the region-specific index ${ }^{19}$ We use percentage deviations of the index from country-specific averages. This index represents the price of country bonds on the secondary market; as such, it is inversely related to the cost of credit. Thus, we expect the demand curve to have a positive slope with respect to this price measure.

The EMBI Global indexes only go as far back as January 1994; therefore, our analysis of demand and supply is limited to the 1994-2004 time period. However, we still capture the effects of currency crises that occurred up to two years prior to January 1994, which amounts to 25 currency crises analyzed.

\footnotetext{
${ }^{19}$ We use the Middle East index for Bahrain and Saudi Arabia; the Asia index for Hong Kong, India, and Singapore; the "Non-Latin" index for the Czech Republic, Romania, and Slovakia.
} 


\subsection{Demand and supply controls: $\mathrm{X}_{\mathrm{it}}^{\mathrm{d}}$}

The control variables are indexes that describe different dimensions of the economy ${ }^{20}$ In each case, the variables are used as percentage deviations from their 25-year country-specific average from 1980 to 2004 on a monthly basis. All the indexes described below are lagged by one month because we are not identifying the exact date of the currency crisis ${ }^{21}$

Since many of the variables we would like to control for are highly correlated, we construct the indexes using the method of principal components. Because a principal component is a linear combination of the variables that enter it, in cases when some variables are missing, other weights can be rescaled to compensate for missing variables. In this way, many of the gaps in the data may be filled, which in our case of many missing observations is the main advantage of using these indexes.

We group the variables in the following categories, summarized in Table 2. The Appendix provides details on the construction of the indexes. For each of these indexes, we use only the first principal component in our estimation.

- International competitiveness. A country's international competitiveness affects the profitability of firms in both the export and in the import-substitution sectors and therefore their demand for credit. It also reflects a country's ability to bring in enough foreign currency to service its foreign debt and thus will affect foreign investors' interest in the country. The following variables are used to construct the index: terms of trade, change in current account, index of the market prices of the country's export commodities 22 and volatility of export revenues. This index is scaled by a measure of trade openness - the ratio of trade volume (sum of exports and imports) to GDP.

\footnotetext{
${ }^{20}$ We draw on the broad empirical literature on emerging market spreads to select our variables (Eichengreen, Hale, and Mody, 2001; Eichengreen and Mody, 2000a; Eichengreen and Mody, 2000b; Gelos, Sahay, and Sandleris, 2004; Kaminsky, Lizondo, and Reinhart, 1998; Mody, Taylor, and Kim, 2001).

${ }^{21}$ This turns out not to make much difference in our estimates compared to the case when they are not lagged or when they are lagged by one year.

${ }^{22}$ Many emerging markets rely heavily on the export of a small number of commodities. We identify up to five of these commodities (or commodity groups) for each country and merge these data with monthly commodity prices from the Global Financial Data and the International Financial Statistics. For each commodity, we calculate monthly percentage deviations from its 25-year average (1980-2004). For each country and each month, we construct the index as a simple average of relevant deviations of commodity prices. If a country is exporting a variety of manufactured goods and does not rely on commodity exports, this index is set to zero.
} 
- Investment climate and monetary stability. This index accounts for the short-run macroeconomic situation in the country. It reflects the demand for investment, the availability of domestic funds, and foreign investors' interest in the country. This index is constructed using the following variables: ratio of debt service to exports, ratio of investment to GDP, real interest rate, ratio of lending interest rate to deposit interest rate, inflation rate, ratio of domestic credit to GDP, and change in the domestic stock market index.

- Financial development. The level of development of the financial market affects domestic funding opportunities for firms and, therefore, their demand for foreign credit. This index is based on the ratio of stock market capitalization to GDP, the ratio of commercial bank assets to GDP, and the degree of financial account openness, which reflects how easy it is for firms to access foreign capital directly.

- Long-run macroeconomic prospects. The economy's growth prospects affect the investment demand of firms. This index is based on the ratio of total foreign debt to GDP, the growth rate of real GDP, the growth rate of nominal GDP measured in U.S. dollars, and the unemployment rate.

In addition to the indexes we include indicators for banking crises (Hutchison and Noy, 2005) and for the sovereign debt crises as defined by Arteta and Hale (2006). We combine renegotiations and agreement indicators to create a single "debt crisis" indicator, which is equal to one either in the month of the onset of renegotiations or in the month of debt restructuring that was not preceded by a period of debt negotiations.

All of the above variables are included in reduced form, demand, and supply equations.

\subsection{Supply controls: $\mathrm{X}_{\mathrm{it}}^{\mathrm{s}}$}

The following variables are included in the reduced form equation and in the supply (price) equation. We believe that they do not directly affect the demand for foreign funds by emerging market private borrowers. 
Global supply of capital. This index reflects the availability of capital in general, changes in investors' risk attitude, and their willingness to provide capital to emerging markets. This index is constructed on the basis of an investor confidence index, the growth rate of the U.S. stock market index, the U.S. Treasury rate, the volume of gross international capital outflows from OECD countries, and Merrill Lynch High Yield Spreads. All variables are presented as percentage deviations from their 25-year averages. Two principal components are retained and capture $65 \%$ of the variance. This index is not country-specific and therefore does not affect an individual country's changes in its demand for credit.

Some creditors are not able or willing to lend to the countries that do not have an IMF agreement in place; therefore, the supply of credit to these countries can be adversely affected, especially in the aftermath of financial crises. We use the variable that is equal to one if either a stand-by or an extended funds facility is in place for each month for a given country. Since the IMF funding is extended to sovereigns, they might affect sovereign demand for funds from commercial creditors, but are not likely to affect private demand for foreign credit directly.

\section{Empirical findings}

We first analyze whether there is a reduction in credit due to currency crises as defined above and then analyze demand and supply effects separately. We first focus on the long run — including our main explanatory variable for up to three years. We then repeat the analysis with monthly indicators of the event. The coefficients in the regressions are easy to interpret: Since the dependent variable (amount of credit) is defined as a percentage deviation from the mean, the coefficients on binary variables indicate the percentage change (relative to the mean) of the dependent variable if the indicator value switches from 0 to 1.

\subsection{Reduced form results}

The results of the reduced form analysis that tests for a decline in credit in the aftermath of a currency crisis are presented in Tables 3 and 4 . Table 3 reports the results for the regressions with credit measured in U.S. dollars, while Table 4 reports the results with credit measured in 
the country's local currency. Since most of the costs that firms incur are in local currency, while foreign credit is usually denominated in a foreign currency, firms might reduce their demand for foreign credit when measured in dollars, while borrowing the same amount in local currency. Since most borrowing occurs in the foreign currency, we translate borrowing into local currency using the average exchange rate for each month, and then discount the measure by the local CPI ${ }^{23}$ It turns out that the decline in credit following a currency crisis is roughly the same whether it is measured in U.S. dollars or in local currency. We proceed with a detailed discussion of the results in Table 3 and merely point out any differences that arise in Table 4.

In Table 3, the dependent variable is the percentage deviation in the foreign credit measured in U.S. dollars received by the private sector. The first three columns report the results of our baseline specification, while the last three present alternative econometric specifications. In particular, we are concerned that borrowing by a given country could be correlated over time, which would lead to incorrect estimates of the variance-covariance matrix and therefore incorrect standard errors. We address this issue in columns (4) and (5). We are also concerned that our left-hand side variables are truncated at -100 on the left and +100 on the right, thus, in column (6), we estimate a Tobit regression.

- Column (1) presents the results that are obtained without including any of the control variables described in the previous section. We can see that, if we do not control for fundamentals, the decline in credit after currency crises events is large - over $30 \%$ in the first two years after the event, only subsiding in the third year. If measured in local currency, the credit declines even more, by over $40 \%$ in the first year.

- Column (2) includes our control variables, except for the effects of debt crisis. We can see that the effect of currency crises is now smaller, suggesting that some of the decline in credit we observed in the first column is due to worsening fundamentals. However, the remaining effect is still large (over 25\%) and significant in the first year ${ }^{24}$ Therefore, it appears that,

\footnotetext{
${ }^{23}$ Prices tend to adjust quite slowly after currency crises (Burstein, Eichenbaum, and Rebelo, 2002; Burstein, Eichenbaum, and Rebelo, 2005), thus our "real local currency" measure of credit is quite different from the one measured in dollars. We are using the average rather than end-of-period exchange rate for two reasons: we are converting the flow of borrowing that occurred throughout the month; end-of-period exchange rate is more likely to be affected by noise trading than average exchange rate.

${ }^{24}$ One must note, however, that the differences in coefficients across specifications are not statistically significant.
} 
conditional on fundamentals, credit recovers faster than the fundamentals themselves. The same is true if credit is measured in local currency.

- As shown in column (3), the effects of currency crises decline further if we control for the effects of sovereign debt crises, but not by much.

- In column (4), we allow for errors to be correlated over time and find that the correlation coefficient is less than 0.10 and that the rest of our results are almost identical to those in column (3). One exception is that now the decline in credit in the second year after a currency crisis becomes significant, which is due to a reduction in the standard error - the point estimate remains the same.

- In column (5), we include a lagged dependent variable interacted with country fixed effects, thus allowing for a different persistence of deviations in credit from the mean in different countries ${ }^{25}$ Again, our baseline results are not affected - the coefficients of interest are now smaller, but due to the lagged dependent variable on the right-hand side, they are not directly comparable with the baseline model.

- In column (6), we estimate a Tobit regression with truncation points at -100 and +100 . Again, the magnitudes of coefficients in this regression are not directly comparable to the baseline model. Nevertheless, we observe the same pattern qualitatively.

While it is difficult to discuss the signs of the coefficients on our indexes, we can see that the coefficients on other controls, IMF agreements, banking crises and debt crises, are of the expected sign and are statistically significant.

In what follows, we use the specification in column (3) of Table 3 as a baseline. Since the borrowing takes place in foreign currency and it appears that measuring it in local currency does not make a difference, in the following regressions our dependent variable is a percentage change in foreign credit to the private sector measured in U.S. dollars.

To analyze how fast the effect of currency crises wears out, we re-estimate the regression in column (3) of Table 3 with monthly rather than annual dummy variables for the lagged effects of currency

\footnotetext{
${ }^{25}$ In a separate regression we include only the lagged dependent variable, without interactions. The results are very similar and are not reported.
} 
crises. We also include 12-month leads to control for simultaneity and expected currency crises. The estimates and their individual 5\% confidence intervals are presented on Figure 2. We can see that the decline in credit seems to last for two years, which is confirmed by the F-test, presented below the graph, although it is larger in the first five months after the currency crisis. We also find a significant decline of about $15 \%$ before the currency crisis, suggesting that either a currency crisis is expected or there is a sudden stop in capital flows that both reduces credit and leads to a currency crisis ${ }^{26}$ In the latter case, there is still an independent effect of the currency crisis as credit declines further after a currency crisis occurs.

\subsection{Demand and supply effects}

We now turn to demand and supply effects. Since we discovered that there is some decline in credit in the three months prior to a currency crisis, we include an indicator for three months before the event. In addition, we split the effects of the first year into two half-year indicators to analyze how fast the effects subside ${ }^{27}$ The results are presented in Table 5. The number of observations is smaller because price data only go back to 1994.

First we note, reassuringly, that the coefficient on the price in the demand equation (labelled "Amount") is positive and statistically significant. Since the price is measured as a market value of the debt, it is the inverse of the cost of credit, and therefore we would expect the demand for credit to depend positively on the market value of debt. Our estimated elasticity of demand suggests that a $10 \%$ increase in the market value of the debt would increase the demand for credit by $3-4 \%$. Moreover, the decline in the market value of the debt means an increase in the cost of borrowing and thus can be interpreted as a decline in the supply of credit.

In Model 1, presented in columns (1) and (2), the supply equation, labelled "Price," does not include the controls for fundamentals. As column (1) shows, we observe a large decline in the market value of the debt that persists for two years, with a decline of over $20 \%$ in the first year and over $10 \%$ in the second year. Once we control for fundamentals (Model 2, column(3)), we find that

\footnotetext{
${ }^{26}$ We address this simultaneity problem in the robustness tests section.

${ }^{27}$ Including instead the same set of dummy variables as in Table 4 gives us the same results. We proceed with the more detailed period dummies, however, because they give us more information.
} 
a reduction in the supply of credit is partly due to worsening fundamentals: the decline in credit is now about $16 \%$ in the second part of the first year. However, it is still persistent.

In both Models 1 and 2, we observe a dramatic decline in the demand for credit, on the order of $40 \%$ in the first five months after a currency crisis. However, this demand effect is very short-lived

— it is only borderline significant in the next half a year, and is no longer statistically significant in the second year in both models.

Controlling for the effects of debt crisis, Model 3 does not bring about many changes, especially in the supply regression (column (5)). Once we control for the effects of debt crises, we can see even more clearly that the decline in demand for credit does not persist after the first five months following the currency crisis.

We can also see in these regressions that neither a decline in supply nor a decline in demand are statistically significant in the three months prior to the currency crisis. This observation is reassuring in the sense that simultaneity due to sudden stops does not appear important, as we verify in the robustness tests.

Thus, we can conclude from this section that we indeed observe a credit crunch in the aftermath of currency crises, which is consistent with the view that balance sheets worsen due to currency depreciation. This finding provides a potential explanation for the decline in investment associated with currency crises.

\subsection{Robustness tests and further analysis}

In this section we conduct some additional tests. The results are not reported but can be obtained from the authors upon request.

\section{Definition of a currency crisis}

First of all, we test whether our results are sensitive to the definition of the a currency crisis. We construct a variable for currency crisis based on the bilateral exchange rate vis-a-vis the U.S. and the CPI in the U.S. and the country of interest. Not surprisingly, the set of events we define 
through the use of this variable is almost identical to the one presented in Table 1 and therefore all the results remain the same. We also alter the length of the tranquil period required before the new crisis can occur, which we initially set to three months. Setting it to one, two, or four months only alters our set of crises very slightly and therefore does not affect the results of the regression analysis.

Next, we re-estimate all our models with a new threshold for the change in the REER set to 15\% (39 episodes in our sample). We find very similar results to our baseline specification for our reduced-form and supply equations, while the decline in demand in the regression reported in column (6) of Table 5 is no longer significant, even in the first five months after the currency crisis. Overall, the basic message of the paper and the estimated magnitudes of the decline in credit remain unchanged.

We re-estimate our model by replacing the currency crisis indicators with a continuous variable that measures the percentage change in the REER in each month. We find no significant effects of this variable, whether contemporaneous or lagged, in a reduced-form specification or in the demand equation, which suggests that our results are indeed driven by currency crises. We do find a significant decline in the supply of credit due to contemporaneous or lagged real depreciation. This finding is consistent with our evidence of the credit crunch.

We also re-estimate our model by separating those depreciation episodes that were devaluations or switches from a preannounced peg to a floating regime from those that were depreciations under float. We find that the decline in credit occurs in both cases but is larger and more persistent in the case of a regime switch ${ }^{28}$ We further find that, while the decline in the supply of credit is observed in the aftermath of both types of currency crises, which is again consistent with the balance-sheetdriven credit crunch, the decline in demand for credit only occurs after regime switches.

\section{Dual debt-currency crises}

\footnotetext{
${ }^{28}$ We use Reinhart and Rogoff (2004) exchange rate classification to determine regime switch. In particular, we define a regime switch as a change from a peg to a free-falling regime.
} 
In our treatment of currency crises and debt crises as separate events, we implicitly assume that when the two occur at the same time, their effects are additive. To test whether this assumption is appropriate, we create the indicators to describe three types of crises: dual crises (defined as currency crises and debt crises occurring within three months of each other), currency crises not accompanied by debt crises, and debt crises not accompanied by currency crises. We find 23 dual crises in our overall sample and only three crises in the sample for which we can analyze demand and supply.

Consistent with our findings here and in Arteta and Hale (2006), we find that credit declines by about $25 \%$ in the first year and by $15 \%$ in the second year after the currency crisis, and by $30 \%$ for over two years after the debt crisis. However, when the crises occur at the same time, credit declines by about $35 \%$ in the first year and about $25 \%$ in the second year. Furthermore, the decline in credit due to a credit crunch appears to be almost exactly additive: in the first year after a currency crisis, the decline in supply is about $20 \%$, in the first year after a debt crisis, it is about $10 \%$, and in the first year after a dual crisis, it is $29 \%$. The decline in demand for credit after dual crises, on the other hand, appears to be driven mostly by the debt crises, which have a larger effect on demand 29

\section{Measure of credit}

Since our measure of fluctuations in credit is constructed from microlevel data, we might be missing an important chunk of the private sector borrowing. From the World Bank's Global Development Finance (GDF) we gathered the series on private nonguaranteed disbursements and repayments (of principal and interest). Unfortunately, the GDF series are only of annual frequency. We compared the gross disbursement series to our total amount borrowed, aggregated by year, and found that they are very similar, with an overall correlation coefficient of 0.63 and a mean about twice as large as our measure.

First, we replicated our results using the percentage deviation from the country mean in gross disbursements, deflated by U.S. CPI (sum of bonds and bank loans). We find that both the

\footnotetext{
${ }^{29}$ These latter results should be interpreted with care, of course, since in this shorter time period we only have three dual crises.
} 
reduced-form and the demand-supply results are completely unaffected by the use of this measure instead of the original one. Because the GDF measure does not vary month-to-month and because we lose five countries for which GDF data are not available, some of the coefficients are estimated less precisely. However, the coefficients that are significant in our benchmark regressions remain significant with the alternative measure of credit.

Next, we test whether our results are sensitive to using a measure of net borrowing (disbursements minus repayments), rather than gross borrowing. We construct the measure of percentage deviations from net borrowing in the same way as above and use it as our dependent variable. In the reduced-form regression, the only change is that there is no longer a reduction in credit two years after a currency crisis. The coefficient now is small and positive, although, as before, it is not significantly different from zero. In the demand-supply regressions, we find that the supply results are not affected (this is not surprising, since nothing is altered in the supply equation), while the decline in demand in the first five months after a currency crisis is a lot larger (about 60\%), persists for the next six months (a $20 \%$ decline), and is reversed to $20 \%$ increase in demand in the second year. Not only does this suggest that firms do not demand as much credit after currency crises, but also that they increase their repayments of existing debt in the first year after crises.

To investigate this further, we revert to using the original measure of credit on the left-hand side and add a measure of repayment (in percentage changes from the country mean) as a control variable. We find that our reduced-form results are largely unaffected, while a $1 \%$ in repayment increases borrowing by $0.12 \%$. In the demand-supply model, where we include the measure of repayment in both equations, both supply and demand are basically unaffected, while $1 \%$ increase in repayment increases the price of bonds by $0.12 \%$ and lowers the demand for credit by $0.14 \%$.

\section{Other tests}

We are concerned about the simultaneity problem that could arise due to sudden stops in capital flows (Calvo, 1998). We now include the indicator for a sudden stop year in our regressions to see whether our results are robust to such a control. Since a simple sudden stop indicator would be endogenous with respect to our left-hand side variable, we use a "systemic sudden stop" indicator 
constructed by Calvo, Izquierdo, and Talvi (2006) that relies less on country-specific information. For the countries not covered in Calvo, Izquierdo, and Talvi (2006), we use the sudden stop indicator from Frankel and Cavallo (2004). We find that adding such an indicator does not alter our coefficients of interest at all. Moreover, the sudden stop indicator does not enter significantly in our supply equation, while it enters positively in our reduced form and demand equation, suggesting that endogeneity of this indicator can indeed be a problem.

To see whether the development of the emerging markets' international bond market in the early 1990s had an important effect, and because private foreign credit was less important in the 1980s, we re-estimate the regressions in Table 4, splitting the sample into 1980-1989 and 1990-2004 time periods. We find that the decline in credit in the 1980s (32 episodes of currency crises) was less than $10 \%$ and only lasted one year, while the decline in the 1990s (31 episodes) was about 28\% in the first year and $17 \%$ in the second year 30 This leads us to suspect that our results might be driven mainly by bond issuance. Thus, we re-estimate our model with just the loans and just the bond issuance on the left-hand side. We find, however, that our main results are driven primarily by the loan market, as the decline in bond credit is smaller and not statistically significant 31

We were interested in estimating whether all the sectors are equally affected by the currency crises. In contrast to the effects of debt crises that are different for financial, exporting, and non-exporting sectors (Arteta and Hale, 2006), we find that the effects of currency crises are roughly the same across these sectors.

We re-estimated our model adding 12-month fixed effects to control for any possible seasonality. While we find that credit in the months of January and February tends to be lower, this effect does not change our results.

When the political situation in a country is unstable, it introduces uncertainty and leads to a decline in firms' investment and their demand for credit; furthermore, it may lead to foreign investors' concerns about their ability to collect their assets in the future. We used the measure of political risk from the International Country Risk Guide to account for this. While this index does enter significantly with the correct sign in most regressions, it does not affect our qualitative or quan-

\footnotetext{
${ }^{30}$ Our demand and supply estimation is limited to the sample of 1994-2004 due to price data availability.

${ }^{31}$ This is not a surprise given a much smaller number of bond issues compared to loan contracts.
} 
titative conclusions. However, it does limit our sample size and therefore reduces the significance level of some coefficients.

We experimented with lagging our indexes by 3, 6, and 12 months and found that while the coefficients on indexes do change, our main results are not affected.

Finally, given the large degree of heterogeneity in the data, we re-estimated the model by estimating time-series regressions for each country and taking a simple average of the coefficients across countries. The coefficients of interest obtained in this manner are very close to those we estimate in our fixed effects specifications, thus confirming that the effects we find are indeed systematic and robust.

\section{Conclusion}

We analyze a data set built on the firm-level data in order to examine the effects of currency crises on the foreign credit to the private sector. Controlling for fundamentals and the effects of sovereign debt crises, we find that foreign credit to the private sector declines by about $25 \%$ in the first year after a currency crisis, and that this decline is especially large in the first five months after the crisis. This decline is persistent, substantial, and robust.

We find that both demand and supply of credit take a substantial hit after currency crises. However, only the decline in supply is persistent and lasts for over two years, while the decline in demand, although large in the first five months after a crisis, wears out quickly. These results are consistent with the view that currency crises lead to balance-sheet effects that in turn can worsen credit rationing: Since balance-sheet problems take a while to resolve, the decline in supply of credit is persistent.

Thus, we provide evidence that may help explain the large scale of economic downturn as well as the decline in investment activity in the aftermath of currency crises. 


\section{References}

Aghion, P., P. Bacchetta, and A. BanerJee (2001): "Currency crises and monetary policy in an economy with credit constraints," European Economic Review, 45(7), 1121-1150.

(2004): "A Corporate Balance-Sheet Approach to Currency Crises," Journal of Economic Theory, 119(1), 6-30.

Arteta, C., And G. Hale (2006): "Sovereign Debt Crises and Credit to the Private Sector," Pacific Basic Working Paper 2006-21.

Bernanke, B., And M. Gertler (1989): "Agency Costs, Net Worth, and Business Fluctuations," American Economic Review, 79(1), 14-31.

Blalock, G., P. J. Gertler, and D. I. Levine (2004): "Investment Following a Financial Crisis: Does Foreign Ownership Matter?," Paper presented at SCCIE workshop on "Firms in Emerging Markets" May 20, 2005.

Bris, A., And Y. Koskinen (2002): "Corporate Leverage and Currency Crises," Journal of Financial Economics, 63(2), 275-331.

Burstein, A. T., M. Eichenbaum, and S. T. Rebelo (2002): "Why Are Rates of Inflation So Low After Large Devaluations?," NBER Working Paper No. W8748.

Burstein, A. T., M. Eichenbaum, and S. T. Rebelo (2005): "Large Devaluations and the Real Exchange Rate," Journal of Political Economy, 113(4), 742-784.

Calomiris, C. W., and R. G. Hubbard (1990): "Firm Heterogeneity, International Finance, and 'Credit Rationing'," The Economic Journal, 100(399), 90-104.

Calvo, G. (1998): "Capital Flows and Capital Market Crises: The Simple Economics of Sudden Stops," Journal of Applied Economics, 1, 35-54.

Calvo, G. A., A. Izquierdo, and E. Talvi (2006): "Phoenix Miracles in Emerging Markets: Recovering without Credit from Systemic Financial Crises," NBER Working Paper 12101.

Cespedes, L. F., R. Chang, and A. Velasco (2003): "IS-LM-BP in the Pampas," IMF Staff Papers, 50, 143-56, Special Issue.

Desai, M. A., C. F. Foley, and K. J. Forbes (forthcoming): "Financial Constraints and Growth: Multinational and Local Firm Responses to Currency Crises," Review of Financial Studies.

Eichengreen, B., G. Hale, And A. Mody (2001): "Flight to Quality: Investor Risk Tolerance and the Spread of Emerging Market Crises," in International Financial Contagion, ed. by S.Classens, and K.Forbes. Kluwer.

Eichengreen, B., and R. Hausmann (1999): "Exchange Rates and Financial Fragility," NBER Working Papers: 7418.

Eichengreen, B., And A. Mody (2000a): "Lending Booms, Reserves and Sustainability of ShortTerm Debt: Inferences from the Pricing of Syndicated Bank Loans," Journal of Development Economics, 63(1), 5-44. 
(2000b): "What Explains Changing Spreads on Emerging-Market Debt? Fundamentals or Market Sentiment?," in The Economics of International Capital Flows, ed. by S. Edwards. University of Chicago Press.

Eichengreen, B., A. K. Rose, and C. Wyplosz (1996): "Contagious Currency Crises," Scandinavian Journal of Economics, 98, 463-484.

Frankel, J. A., And E. A. Cavallo (2004): "Does Openness to Trade Make Countries More Vulnerable to Sudden Stops, or Less? Using Gravity to Establish Causality," NBER Working Paper 10957.

Gelos, R. G., R. Sahay, and G. Sandleris (2004): "Sovereign Borrowing by Developing Countries: What determines market access?," IMF Working Paper.

Glick, R., and M. Hutchison (2005): "Capital Controls and Exchange Rate Instability in Developing Countries," Journal of International Money and Finance, 24(3), 387-412.

Gupta, P., D. Mishra, and R. Sahay (2003): "Output Response to Currency Crises," IMF Working Papers 03/230.

Hale, G. (2007): "Bonds or Loans? The Effect of Macroeconomic Fundamentals," Economic Journal, 117, 196.

Hutchison, M., And I. Noy (2002): "Output Costs of Currency and Balance of Payments Crises in Emerging Markets," Comparative Economic Studies, XLIV, 27-44.

(2005): "How Bad are Twins? Output Costs of Currency and Banking Crises," Journal of Money, Credit and Banking, 37(4), 725-752.

Kaminsky, G., S. Lizondo, and C. M. Reinhart (1998): "Leading Indicators of Currency Crises," IMF Staff Papers, 45, 1-48.

Krugman, P. (2001): "Analytical Afterthoughts on the Asian Crisis," in Financial market integration and international capital flows, ed. by D. Irwin, Gregor; Vines, pp. 389-97. Elgar Reference Collection.

Lane, P., and G. M. Milesi-Ferretti (1999): "The External Wealth of Nations: Measures of Foreign Assets and Liabilities for Industrial and Developing Countries," IMF Working Paper No. $99 / 115$.

Mason, R. (1998): "An Options-based Model of Equilibrium Credit Rationing," Journal of Corporate Finance, 4, 71-85.

Mody, A., M. P. TAYlor, And J. Y. Kim (2001): "Modelling Fundamentals for Forecasting Capital Flows to Emerging Markets," International Journal of Finance and Economics, 6, 201216.

Reinhart, C., and K. Rogoff (2004): "The Modern History of Exchange Rate Arrangements: A Reinterpretation," The Quarterly Journal of Economics, 119(1), 1-48.

Shaghil, A., C. J. Gust, S. B. Kamin, and J. Huntley (2002): "Are depreciations as contractionary as devaluations? A comparison of selected emerging and industrial economies," International Finance Discussion Paper 737, Board of Governors of the Federal Reserve System. 
Stiglitz, J. E., And A. Weiss (1981): "Credit Rationing in Markets with Imperfect Information," American Economic Review, 71(3), 393-410. 


\section{Appendix}

\section{Indexes}

The indexes were constructed using the full sample with weights zero assigned to missing variables. Here we present the linear combinations of the variables that are our indexes. All the variables enter as their percentage deviations from the country-specific means in a standardized form, which renders them unit-free and comparable.

$$
\text { Index } 1=(-0.60 * T O T+0.013 * \dot{C A}+0.68 * E P I+0.30 * V O L T) * T O,
$$

where

$\begin{array}{lll}\text { TOT } & \text { Terms of Trade } & \mathrm{Up}=\text { Improvement } \\ \text { CA } & \text { Change in CA } & \mathrm{Up}=\text { Improvement } \\ \text { EPI } & \text { Export Price Index } & \mathrm{Up}=\text { Increase } \\ \text { VOLT } & \text { Trade Volatility } & \mathrm{Up}=\text { Increase } \\ \text { TO } & \text { Trade Openness }(\mathrm{EX}+\mathrm{IM}) / \mathrm{GDP} & \mathrm{Up}=\text { Increase }\end{array}$

$$
\begin{aligned}
\text { Index } 2= & 0.033 * S C R+0.053 * D S / E X-0.67 * I / Y+0.19 * R I R \\
& -0.16 * L R / D R-0.045 * I N F L+0.70 * D C / Y+0.0015 * \dot{S} I
\end{aligned}
$$

where

$\begin{array}{lll}S C R & \text { Sovereign Credit Risk } & \mathrm{Up}=\text { Lower risk } \\ D S / E X & \text { Debt Service/Exports } & \mathrm{Up}=\text { Increase } \\ I / Y & \text { Investment/GDP } & \mathrm{Up}=\text { Increase } \\ R I R & \text { Real Interest Rate } & \mathrm{Up}=\text { Increase } \\ L R / D R & \text { Lending Rate/Deposit Rate } & \mathrm{Up}=\text { Increase } \\ I N F L & \text { Inflation Rate } & \mathrm{Up}=\text { Increase } \\ D C / Y & \text { Domestic Credit/GDP } & \mathrm{Up}=\text { Increase } \\ \dot{S I} & \text { Change in Stock Market Index } & \mathrm{Up}=\text { Increase }\end{array}$

$$
\text { Index } 3=0.60 * O P E N+0.55 * B A+0.58 * S M
$$

where

$\begin{array}{lll}O P E N & \text { Financial Account Openness } & \mathrm{Up}=\text { More open } \\ B A & \text { Commercial Bank Assets/GDP } & \mathrm{Up}=\text { Increase } \\ S M & \text { Stock Market Capitalization/GDP } & \mathrm{Up}=\text { Increase }\end{array}$

$$
\text { Index } 4=0.40 * F D / Y+0.61 * \hat{Y}-0.50 * \hat{P Y}+0.46 * U
$$

where

$$
\begin{array}{lll}
F D / Y & \text { Foreign Debt/GDP } & \mathrm{UP}=\text { Increase } \\
\hat{Y} & \text { Growth Rate of Real GDP } & \mathrm{Up}=\text { Increase } \\
\hat{P Y} & \text { Growth Rate of GDP in US Dollars } & \mathrm{Up}=\text { Increase } \\
U & \text { Unemployment Rate } & \mathrm{Up}=\text { Increase } \\
& \multicolumn{2}{c}{\text { Index } 5.1=-0.60 * C O+0.34 * C I+0.39 * T R+0.59 * H Y+0.16 * U \hat{S S I},} \\
& \multicolumn{1}{c}{\text { Index } 5.2=0.37 * C O+0.62 * C I+0.55 * T R-0.38 * H Y+0.18 * U \hat{S S},}
\end{array}
$$

where 


$\begin{array}{lll}C O & \text { Gross Capital Outflows from OECD } & \mathrm{Up}=\text { Increase } \\ C I & \text { Investor Confidence Index } & \mathrm{Up}=\text { More confidence } \\ T R & \text { U.S. Treasury Rate } & \mathrm{Up}=\text { Increase } \\ H Y & \text { ML High Yield Spread } & \mathrm{Up}=\text { Increase } \\ U \hat{S S I} & \text { Growth Rate of U.S. Stock Market Index } & \mathrm{Up}=\text { Increase }\end{array}$

\section{Data formats and sources}

\begin{tabular}{|c|c|c|c|}
\hline Variable & Frequency & Units & Source \\
\hline Real effective exchange rate & monthly & Index & JP Morgan - Bloomberg series JBXR* \\
\hline Primary bond issues & by issue & $\#$, U.S.\$ & Bondware \\
\hline spread & by issue & bp & Bondware \\
\hline maturity & by issue & years & Bondware \\
\hline Syndicated loan contracts & by contract & \#, U.S.\$ & Loanware \\
\hline spread & by contract & bp & Loanware \\
\hline maturity & by contract & years & Loanware \\
\hline Terms of trade & annual & index & UNCTAD \\
\hline Current account & monthly & U.S.\$ & IFS line $78 \mathrm{al}$ \\
\hline Real exchange rate & monthly & index & IFS line rec \\
\hline Export commodity prices & monthly & index & Authors' calculations (see text) \\
\hline Exchange rate regime & monthly & list & Reinhart \& Rogoff (2004) \\
\hline Exports & monthly & n.c.units & IFS line $90 \mathrm{c}$ \\
\hline Imports & monthly & n.c.units & IFS line $98 \mathrm{c}$ \\
\hline GDP & monthly & n.c.units & IFS line 99b, GFD \\
\hline Debt service & monthly & U.S.\$ & Joint BIS-IMF-OECD-WB data \\
\hline Investment & monthly & n.c.units & IFS line $93 \mathrm{e}$ \\
\hline Lending rate & monthly & percent & IFS line $60 p$ \\
\hline Deposit rate & monthly & percent & IFS line 601 \\
\hline CPI inflation rate & monthly & percent & IFS line $64 x$ \\
\hline Nominal exchange rate & monthly & n.c./U.S.\$ & IFS line \\
\hline Domestic credit & monthly & n.c.units & IFS line \\
\hline Sovereign credit rating & monthly & index & S\&P, Moody's, EIU \\
\hline Stock market indexes & monthly & index & Ibbotson, GFD, Bloomberg \\
\hline Stock market cap. & monthly & n.c.units & GFD \\
\hline Comm. banks assets & monthly & n.c.units & IFS lines 20-22 \\
\hline Capital access & annual & index & Milken Institute \\
\hline Fin. account openness & annual & index & IMF, Glick and Hutchison (2005) \\
\hline Total foreign debt & quarterly & U.S.\$ & Joint BIS-IMF-OECD-WB data \\
\hline Industrial production & monthly & index & WB \\
\hline Unemployment rate & monthly & percent & IFS line $67 \mathrm{r}, \mathrm{GFD}$ \\
\hline Investor confidence & monthly & index & Yale SOM \\
\hline U.S. stock market index & monthly & index & GFD \\
\hline U.S. Treasury rate & monthly & percent & Federal Reserve \\
\hline Gross capital outflows & monthly & U.S.\$ & Lane and Milesi-Ferretti (1999) \\
\hline EMBI index & monthly & index & J.P.Morgan/Bloomberg \\
\hline IMF program & monthly & binary & IMF web site \\
\hline Banking crisis indicator & annual & binary & Hutchison and Noy (2005) \\
\hline Systemic sudden stop & monthly & binary & Calvo, Izquierdo, and Talvi (2006) \\
\hline Sudden stop & annual & binary & Frankel and Cavallo (2004) \\
\hline Debt restructuring indicators & monthly & binary & Arteta and Hale (2006) \\
\hline
\end{tabular}

Note: See text for description of Bondware and Loanware, GDF is World Bank's Global Development Finance, IFS is International Financial Statistics, GFD is Global Financial Data, EIU is Economist Intelligence Unit, ICRG is International Country Risk Data. 
Figure 1: Foreign borrowing by private firms — six major crises
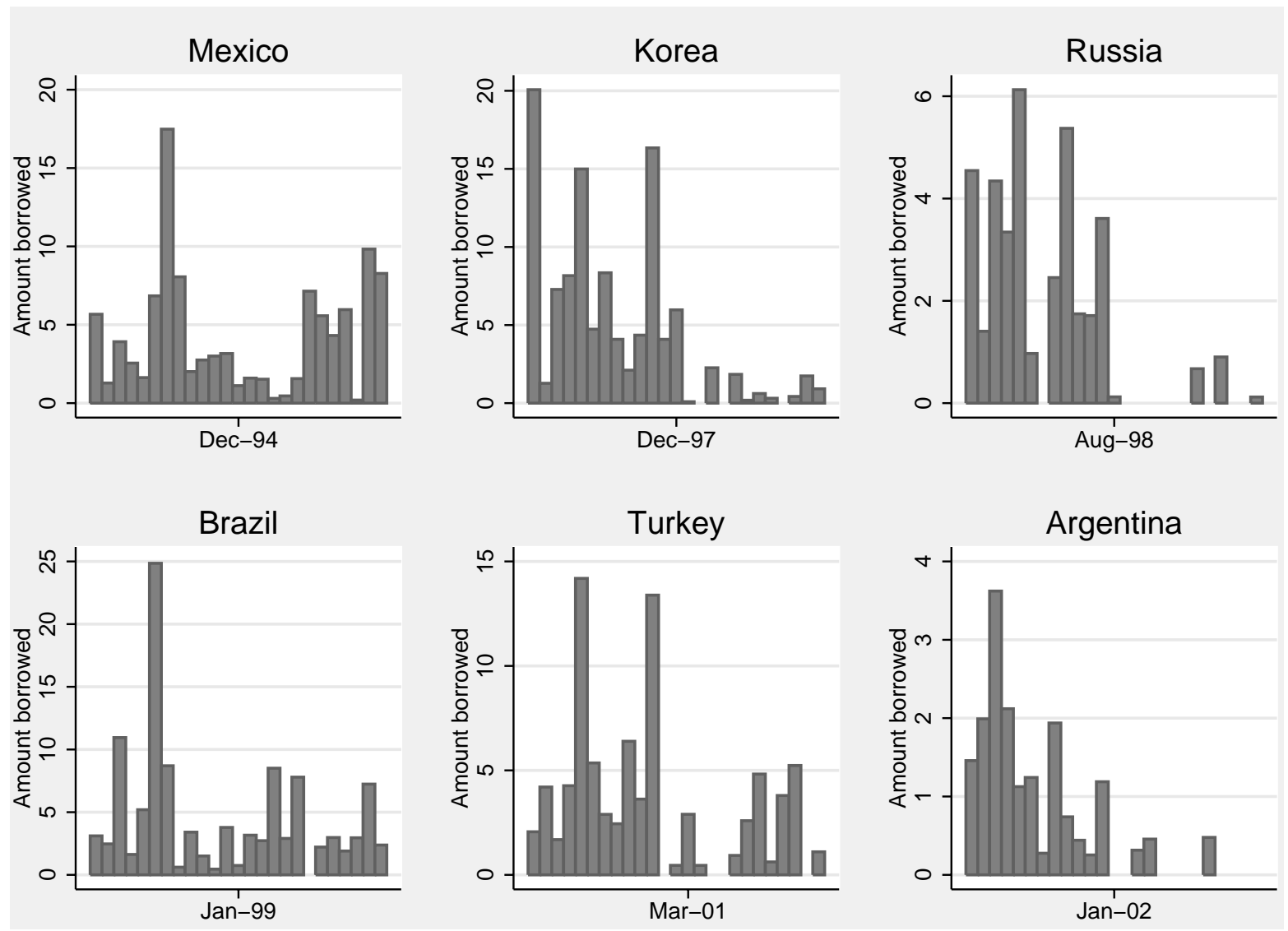

Source: Authors' calculations. In bln. U.S. dollars. 
Figure 2: Monthly estimates of the effects of currency crises

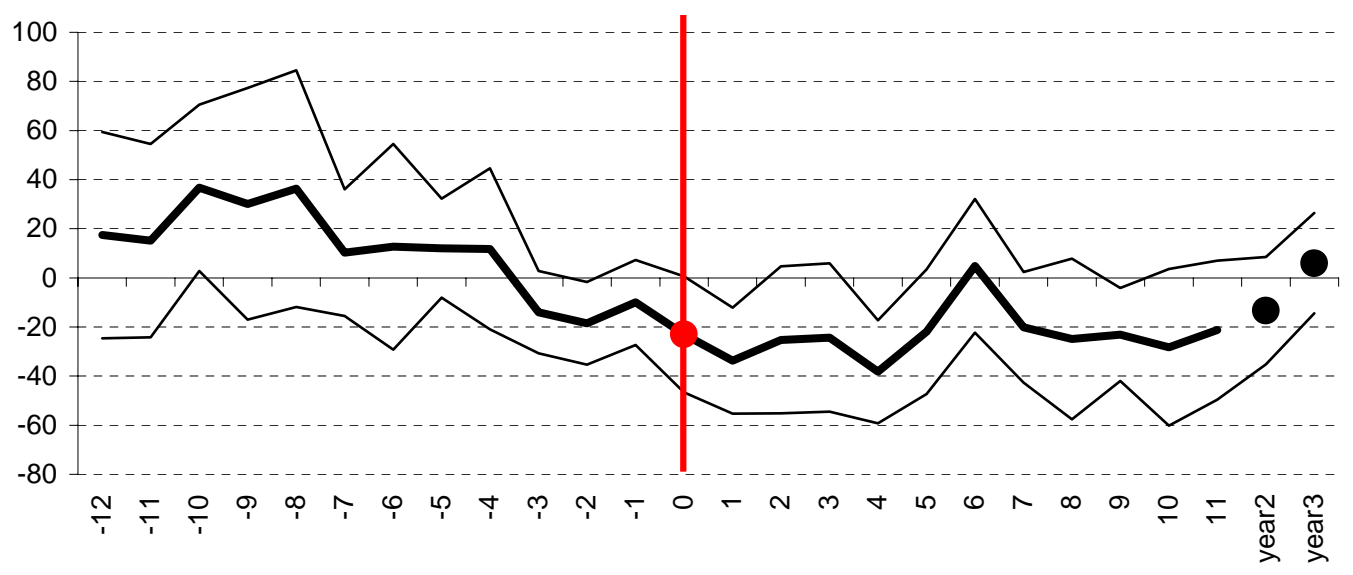

Each point on a thick line represents a $\beta$-coefficient on the appropriate lead or lag of the currency crisis indicator where the dependent variable is total amount borrowed by private sector in percentage deviations from country-specific means. All control variables are included. Thin lines represent $95 \%$ confidence interval for each $\beta$-coefficient.

F-tests:

Prob(total effect in 3 months before is zero) $=0.03$

Prob(total effect in 5 months after is zero) $=0.009$

Prob(total effect in month 6 to 24 after is zero) $=0.09$ 
Table 1: Currency crises in the sample

\begin{tabular}{lcc||lcc}
\hline \hline & & & & \\
Country & Year & Month & Country & Year & Month \\
\hline & & & & & \\
Argentina & 1981 & 4 & Philippines & 1983 & 10 \\
Argentina & 1982 & $1,5,11$ & Philippines & 1986 & 2 \\
Argentina & 1984 & 11 & Romania & 1997 & 1 \\
Argentina & 1985 & 7 & Russia & 1994 & 10 \\
Argentina & 1989 & 4,12 & Russia & 1998 & 8 \\
Argentina & 1991 & 1 & South Africa & 1984 & 7 \\
Argentina & 2002 & 1 & South Africa & 1985 & 1,8 \\
Brazil & 1983 & 2 & South Africa & 1986 & 6 \\
Brazil & 1990 & 4,10 & South Africa & 1998 & 7 \\
Brazil & 1999 & 1 & South Africa & 2001 & 12 \\
China & 1994 & 1 & Thailand & 1984 & 11 \\
Egypt & 2003 & 2 & Thailand & 1997 & 7 \\
India & 1991 & 7 & Thailand & 1998 & 1 \\
India & 1993 & 3 & Turkey & 1994 & 2 \\
Indonesia & 1983 & 4 & Turkey & 2001 & 3 \\
Indonesia & 1986 & 9 & Venezuela & 1984 & 2 \\
Indonesia & 1997 & 10 & Venezuela & 1986 & 12 \\
Indonesia & 1998 & 5 & Venezuela & 1989 & 3 \\
Indonesia & 1999 & 8 & Venezuela & 1994 & 5 \\
Korea & 1997 & 12 & Venezuela & 1995 & 12 \\
Mexico & 1982 & $2,8,12$ & Venezuela & 1996 & 4 \\
Mexico & 1985 & 8 & Venezuela & 2002 & 2 \\
Mexico & 1994 & 12 & Venezuela & 2003 & 1 \\
Peru & 1981 & 2,10 & Venezuela & 2004 & 2 \\
Peru & 1982 & 3 & & & \\
Peru & 1987 & 11 & & & \\
Peru & 1988 & 9 & & & \\
Peru & 1989 & 2,7 & & & \\
Peru & 1990 & 8 & & & \\
Peru & 1991 & 5 & & & \\
\hline \hline & & & & & \\
\hline
\end{tabular}

Countries included in the sample that did not experience a crisis: Bahrain, Chile, Colombia, Czech Republic, Hong Kong, Hungary, Malaysia, Pakistan, Poland, Saudi Arabia, Singapore, Slovakia 
Table 2: Summary of indexes

\begin{tabular}{|c|c|c|c|c|}
\hline Concept & Variables & Shifting & Notes & Indexes \\
\hline $\begin{array}{l}\text { International } \\
\text { competitiveness }\end{array}$ & $\begin{array}{c}\text { Terms of trade } \\
\text { Change in CA } \\
\text { Export commodity prices } \\
\text { Volatility of export revenues }\end{array}$ & $\begin{array}{l}\text { Demand } \\
\text { Supply }\end{array}$ & $\begin{array}{c}\text { Scaled by trade } \\
\text { openness }\end{array}$ & 1 \\
\hline $\begin{array}{l}\text { Investment climate and } \\
\text { monetary stability }\end{array}$ & $\begin{array}{c}\text { Debt service/Exports } \\
\text { Investment/GDP } \\
\text { Real interest rate } \\
\text { Lending rate/Deposit rate } \\
\text { Inflation rate } \\
\text { Domestic credit/GDP } \\
\text { Change in stock market index }\end{array}$ & $\begin{array}{l}\text { Demand } \\
\text { Supply }\end{array}$ & Lagged 1 month & 2 \\
\hline Financial development & $\begin{array}{l}\text { Stock market cap./GDP } \\
\text { Comm. bank assets/GDP } \\
\text { Financial account openness }\end{array}$ & $\begin{array}{l}\text { Demand } \\
\text { Supply }\end{array}$ & Lagged 1 month & 3 \\
\hline $\begin{array}{l}\text { Long-run macroeconomic } \\
\text { prospects }\end{array}$ & $\begin{array}{c}\text { Foreign debt/GDP } \\
\text { Growth rate of real GDP } \\
\text { Growth rate of GDP in USD } \\
\text { Unemployment rate }\end{array}$ & $\begin{array}{l}\text { Demand } \\
\text { Supply }\end{array}$ & Lagged 1 month & 4 \\
\hline Global supply of capital & $\begin{array}{c}\text { Investor confidence index } \\
\text { Growth rate of U.S. stock mkt. index } \\
\text { U.S. Treasury rate } \\
\text { Gross capital outflows from OECD } \\
\text { ML High Yield Spread }\end{array}$ & Supply & Not lagged & $\begin{array}{l}5.1 \\
5.2\end{array}$ \\
\hline
\end{tabular}


Table 3: Effects of currency crises on total amount borrowed (U.S. dollars)

\begin{tabular}{|c|c|c|c|c|c|c|}
\hline & (1) & $(2)$ & $(3)$ & (4) & $(5)$ & $(6)$ \\
\hline Month of crisis & $\begin{array}{c}-32.71^{* *} \\
(13.58)\end{array}$ & $\begin{array}{c}-24.11^{*} \\
(12.71)\end{array}$ & $\begin{array}{c}-24.79 * * \\
(12.33)\end{array}$ & $\begin{array}{c}-21.93^{*} \\
(13.23)\end{array}$ & $\begin{array}{c}-17.39^{*} \\
(10.53)\end{array}$ & $\begin{array}{c}-55.35^{* *} \\
(24.83)\end{array}$ \\
\hline Year 1 since crisis & $\begin{array}{c}-36.77^{* * *} \\
(11.77)\end{array}$ & $\begin{array}{c}-26.30^{* *} \\
(11.01)\end{array}$ & $\begin{array}{c}-25.91^{* *} \\
(10.28)\end{array}$ & $\begin{array}{c}-25.70^{* * *} \\
(5.78)\end{array}$ & $\begin{array}{c}-18.96^{* *} \\
(7.82)\end{array}$ & $\begin{array}{c}-43.94^{* * *} \\
(9.36)\end{array}$ \\
\hline Year 2 since crisis & $\begin{array}{c}-30.51^{* *} \\
(12.14)\end{array}$ & $\begin{array}{c}-17.22 \\
(11.68)\end{array}$ & $\begin{array}{l}-14.12 \\
(11.41)\end{array}$ & $\begin{array}{c}-14.02^{* *} \\
(6.20)\end{array}$ & $\begin{array}{l}-8.78 \\
(9.06)\end{array}$ & $\begin{array}{c}-27.52^{* * *} \\
(9.74)\end{array}$ \\
\hline Year 3 since crisis & $\begin{array}{r}-10.02 \\
(9.89)\end{array}$ & $\begin{array}{c}2.03 \\
(9.97)\end{array}$ & $\begin{array}{c}5.00 \\
(10.29)\end{array}$ & $\begin{array}{c}5.50 \\
(6.56)\end{array}$ & $\begin{array}{l}10.03 \\
(8.15)\end{array}$ & $\begin{array}{c}3.25 \\
(10.13)\end{array}$ \\
\hline Index 1 & & $\begin{array}{l}-7.69 \\
(26.61)\end{array}$ & $\begin{array}{l}-6.91 \\
(26.26)\end{array}$ & $\begin{array}{l}-7.74 \\
(12.51)\end{array}$ & $\begin{array}{c}2.58 \\
(22.13)\end{array}$ & $\begin{array}{l}-14.07 \\
(17.51)\end{array}$ \\
\hline Index 2 & & $\begin{array}{c}4.41 \\
(2.82)\end{array}$ & $\begin{array}{c}2.25 \\
(2.48)\end{array}$ & $\begin{array}{l}2.39^{*} \\
(1.38)\end{array}$ & $\begin{array}{l}1.72 \\
(2.04)\end{array}$ & $\begin{array}{c}12.24^{* * *} \\
(2.50)\end{array}$ \\
\hline Index 3 & & $\begin{array}{l}4.71^{* *} \\
(2.37)\end{array}$ & $\begin{array}{l}4.34^{*} \\
(2.41)\end{array}$ & $\begin{array}{c}3.68^{* * *} \\
(1.02)\end{array}$ & $\begin{array}{c}3.43 \\
(2.37)\end{array}$ & $\begin{array}{c}5.73^{* * *} \\
(1.62)\end{array}$ \\
\hline Index 4 & & $\begin{array}{l}2.45^{* *} \\
(0.97)\end{array}$ & $\begin{array}{l}2.21^{* *} \\
(0.91)\end{array}$ & $\begin{array}{c}2.24^{* *} \\
(1.04)\end{array}$ & $\begin{array}{l}1.73^{* *} \\
(0.81)\end{array}$ & $\begin{array}{c}3.65^{* *} \\
(1.72)\end{array}$ \\
\hline Index 5.1 & & $\begin{array}{c}-14.94^{* * *} \\
(5.52)\end{array}$ & $\begin{array}{c}-15.11^{* * * *} \\
(5.45)\end{array}$ & $\begin{array}{c}-14.29^{* * *} \\
(5.29)\end{array}$ & $\begin{array}{c}-14.92^{* * *} \\
(5.22)\end{array}$ & $\begin{array}{c}-19.90^{* *} \\
(8.29)\end{array}$ \\
\hline Index 5.2 & & $\begin{array}{c}11.44^{* * *} \\
(4.37)\end{array}$ & $\begin{array}{c}12.10^{* * *} \\
(4.44)\end{array}$ & $\begin{array}{c}10.97^{* * *} \\
(3.82)\end{array}$ & $\begin{array}{c}11.23^{* * *} \\
(4.23)\end{array}$ & $\begin{array}{c}14.05^{* *} \\
(6.07)\end{array}$ \\
\hline IMF agreement indicator & & $\begin{array}{c}-19.12^{* * *} \\
(6.75)\end{array}$ & $\begin{array}{c}-14.19^{* *} \\
(6.03)\end{array}$ & $\begin{array}{c}-14.12^{* * *} \\
(3.77)\end{array}$ & $\begin{array}{c}-12.55^{* *} \\
(5.41)\end{array}$ & $\begin{array}{c}-15.54^{* *} \\
(6.09)\end{array}$ \\
\hline Banking crisis indicator & & $\begin{array}{c}-14.24 \\
(10.03)\end{array}$ & $\begin{array}{r}-13.17 \\
(9.96)\end{array}$ & $\begin{array}{c}-13.42^{* * *} \\
(4.97)\end{array}$ & $\begin{array}{c}-13.52^{*} \\
(7.73)\end{array}$ & $\begin{array}{c}-30.85^{* * *} \\
(7.67)\end{array}$ \\
\hline Debt crisis & & & $\begin{array}{c}-29.51^{* *} \\
(13.66)\end{array}$ & $\begin{array}{c}-28.80 * * * \\
(10.93)\end{array}$ & $\begin{array}{c}-28.03^{* *} \\
(13.21)\end{array}$ & $\begin{array}{c}-73.25^{* * *} \\
(21.12)\end{array}$ \\
\hline Year 1 since debt crisis & & & $\begin{array}{c}-31.24^{* * * *} \\
(9.07)\end{array}$ & $\begin{array}{c}-30.71^{* * *} \\
(4.99)\end{array}$ & $\begin{array}{c}-30.27^{* * *} \\
(8.94)\end{array}$ & $\begin{array}{c}-67.83^{* * *} \\
(8.34)\end{array}$ \\
\hline Year 2 since debt crisis & & & $\begin{array}{c}-31.42^{* * *} \\
(8.18)\end{array}$ & $\begin{array}{c}-30.32^{* * *} \\
(5.52)\end{array}$ & $\begin{array}{c}-29.29^{* * *} \\
(8.38)\end{array}$ & $\begin{array}{c}-58.83^{* * *} \\
(8.96)\end{array}$ \\
\hline Observations & 7850 & 6240 & 6240 & 6212 & 5975 & 6240 \\
\hline Adjusted $R^{2}$ & 0.18 & 0.19 & 0.20 & 0.15 & 0.21 & \\
\hline $\operatorname{AR}(1) \rho$ & & & & 0.095 & & \\
\hline
\end{tabular}

Dependent variable: total amount borrowed (USD) in percentage deviations from the mean.

Robust standard errors clustered on country are in parentheses (except (4),(6)).

Year and country fixed effects are included in all regressions.

* significant at $10 \%$; ** significant at $5 \%$; *** significant at $1 \%$.

OLS in columns (1)-(3),(5); ML in (4),(6).

(5) includes lagged dependent variable interacted with country fixed effects. (6) is Tobit. 
Table 4: Effects of currency crises on total amount borrowed (local currency)

\begin{tabular}{|c|c|c|c|c|c|c|}
\hline & $(1)$ & $(2)$ & $(3)$ & (4) & $(5)$ & $(6)$ \\
\hline Month of crisis & $\begin{array}{l}-25.54 \\
(21.12)\end{array}$ & $\begin{array}{c}-8.82 \\
(18.38)\end{array}$ & $\begin{array}{l}-10.40 \\
(19.17)\end{array}$ & $\begin{array}{c}-8.53 \\
(21.34)\end{array}$ & $\begin{array}{l}-20.12 \\
(12.91)\end{array}$ & $\begin{array}{l}-46.06 \\
(28.44)\end{array}$ \\
\hline Year 1 since crisis & $\begin{array}{c}-40.45^{* * *} \\
(14.03)\end{array}$ & $\begin{array}{l}-25.93^{*} \\
(13.81)\end{array}$ & $\begin{array}{l}-26.22^{*} \\
(13.53)\end{array}$ & $\begin{array}{c}-26.06^{* * *} \\
(8.73)\end{array}$ & $\begin{array}{c}-24.16^{* * *} \\
(8.83)\end{array}$ & $\begin{array}{c}-49.53^{* * *} \\
(10.48)\end{array}$ \\
\hline Year 2 since crisis & $\begin{array}{c}-34.10^{* *} \\
(14.38)\end{array}$ & $\begin{array}{l}-21.13 \\
(13.51)\end{array}$ & $\begin{array}{l}-19.38 \\
(13.52)\end{array}$ & $\begin{array}{c}-19.21^{* *} \\
(9.08)\end{array}$ & $\begin{array}{c}-15.06^{*} \\
(8.86)\end{array}$ & $\begin{array}{c}-37.62^{* * *} \\
(10.59)\end{array}$ \\
\hline Year 3 since crisis & $\begin{array}{c}-6.70 \\
(14.59)\end{array}$ & $\begin{array}{c}2.94 \\
(14.72)\end{array}$ & $\begin{array}{c}5.18 \\
(14.72)\end{array}$ & $\begin{array}{c}5.43 \\
(9.52)\end{array}$ & $\begin{array}{c}6.19 \\
(9.24)\end{array}$ & $\begin{array}{c}-4.05 \\
(10.89)\end{array}$ \\
\hline Index 1 & & $\begin{array}{l}-24.84 \\
(24.64)\end{array}$ & $\begin{array}{l}-23.19 \\
(24.24)\end{array}$ & $\begin{array}{l}-23.28 \\
(19.16)\end{array}$ & $\begin{array}{l}-13.25 \\
(27.00)\end{array}$ & $\begin{array}{l}-29.55 \\
(19.96)\end{array}$ \\
\hline Index 2 & & $\begin{array}{c}5.99^{* *} \\
(3.01)\end{array}$ & $\begin{array}{c}4.27 \\
(2.72)\end{array}$ & $\begin{array}{l}4.33^{* *} \\
(2.02)\end{array}$ & $\begin{array}{l}1.04 \\
(2.17)\end{array}$ & $\begin{array}{c}13.28^{* * * *} \\
(2.67)\end{array}$ \\
\hline Index 3 & & $\begin{array}{l}5.59^{*} \\
(2.98)\end{array}$ & $\begin{array}{l}5.34^{*} \\
(3.07)\end{array}$ & $\begin{array}{c}4.83^{* * *} \\
(1.47)\end{array}$ & $\begin{array}{c}3.71 \\
(2.51)\end{array}$ & $\begin{array}{c}7.21^{* * * *} \\
(1.71)\end{array}$ \\
\hline Index 4 & & $\begin{array}{c}2.88^{* *} \\
(1.32)\end{array}$ & $\begin{array}{c}2.48^{* *} \\
(1.21)\end{array}$ & $\begin{array}{l}2.50^{*} \\
(1.48)\end{array}$ & $\begin{array}{c}2.22^{* *} \\
(0.89)\end{array}$ & $\begin{array}{c}3.38^{*} \\
(1.81)\end{array}$ \\
\hline Index 5.1 & & $\begin{array}{c}-21.21^{* * *} \\
(7.62)\end{array}$ & $\begin{array}{c}-21.68^{* * * *} \\
(7.69)\end{array}$ & $\begin{array}{c}-21.19^{* * *} \\
(7.68)\end{array}$ & $\begin{array}{c}-14.88^{* * *} \\
(5.56)\end{array}$ & $\begin{array}{c}-23.84^{* * * *} \\
(8.81)\end{array}$ \\
\hline Index 5.2 & & $\begin{array}{c}17.94^{* * *} \\
(5.77)\end{array}$ & $\begin{array}{c}18.46^{* * *} \\
(5.85)\end{array}$ & $\begin{array}{c}17.72^{* * *} \\
(5.60)\end{array}$ & $\begin{array}{c}11.91^{* * * *} \\
(4.22)\end{array}$ & $\begin{array}{c}19.43^{* * *} \\
(6.40)\end{array}$ \\
\hline IMF agreement indicator & & $\begin{array}{c}-19.86^{* *} \\
(8.61)\end{array}$ & $\begin{array}{c}-15.67^{* *} \\
(7.80)\end{array}$ & $\begin{array}{c}-15.57^{* * *} \\
(5.47)\end{array}$ & $\begin{array}{c}-14.81^{* * *} \\
(5.56)\end{array}$ & $\begin{array}{c}-18.42^{* * * *} \\
(6.56)\end{array}$ \\
\hline Banking crisis indicator & & $\begin{array}{l}-18.01 \\
(12.18)\end{array}$ & $\begin{array}{l}-15.69 \\
(12.67)\end{array}$ & $\begin{array}{c}-16.09^{* *} \\
(7.45)\end{array}$ & $\begin{array}{l}-8.44 \\
(8.14)\end{array}$ & $\begin{array}{c}-26.77^{* * *} \\
(8.70)\end{array}$ \\
\hline Debt crisis & & & $\begin{array}{l}-16.73 \\
(17.90)\end{array}$ & $\begin{array}{c}-16.78 \\
(17.02)\end{array}$ & $\begin{array}{c}-23.98 \\
(16.13)\end{array}$ & $\begin{array}{c}-47.74^{* *} \\
(23.04)\end{array}$ \\
\hline Year 1 since debt crisis & & & $\begin{array}{c}-25.71^{*} \\
(13.25)\end{array}$ & $\begin{array}{c}-25.20^{* * *} \\
(7.25)\end{array}$ & $\begin{array}{c}-30.19^{* * *} \\
(10.10)\end{array}$ & $\begin{array}{c}-58.35^{* * *} \\
(9.00)\end{array}$ \\
\hline Year 2 since debt crisis & & & $\begin{array}{c}-36.72^{* * *} \\
(12.55)\end{array}$ & $\begin{array}{c}-36.48^{* * *} \\
(7.97)\end{array}$ & $\begin{array}{c}-28.73^{* * *} \\
(8.71)\end{array}$ & $\begin{array}{c}-63.15^{* * *} \\
(9.65)\end{array}$ \\
\hline Observations & 7050 & 6121 & 6121 & 6093 & 5825 & 6121 \\
\hline Adjusted $R^{2}$ & 0.13 & 0.14 & 0.14 & 0.21 & 0.16 & \\
\hline $\operatorname{AR}(1) \rho$ & & & & 0.095 & & \\
\hline
\end{tabular}

Dependent variable: total amount borrowed (loc.cur.) in percentage deviations from the mean. Robust standard errors clustered on country are in parentheses (except (4),(6)).

Year and country fixed effects are included in all regressions.

* significant at $10 \%$;** significant at $5 \%$; *** significant at $1 \%$.

OLS in columns (1)-(3),(5); ML in (4),(6).

(5) includes lagged dependent variable interacted with country fixed effects. (6) is Tobit. 
Table 5: Effects of currency crises on demand and supply of funds

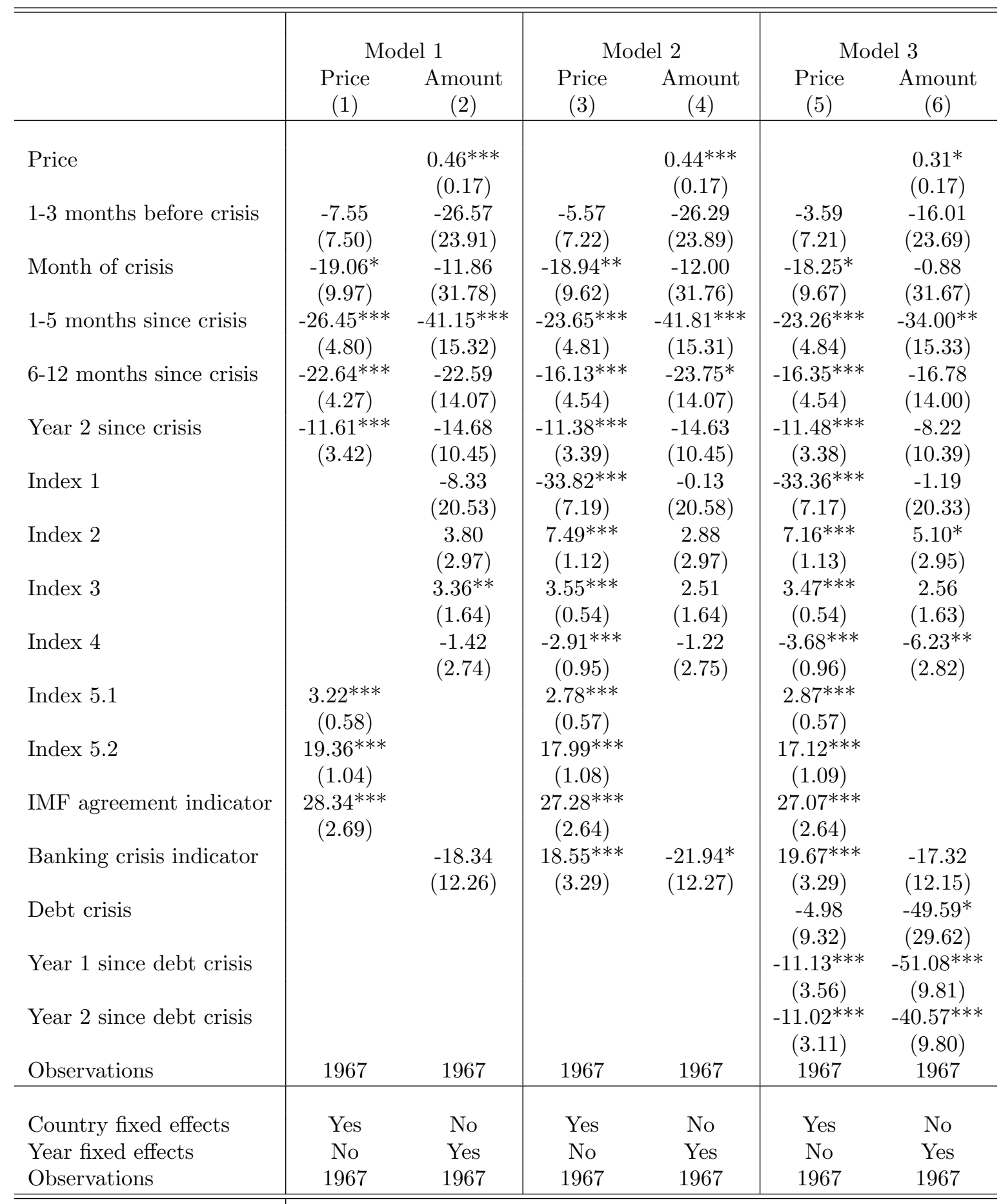

Three-stage least squares estimates

Dependent variables (in percentage deviation from the mean):

Price $=$ the value of EMBI; Amount $=$ Total amount borrowed (USD)

Robust standard errors clustered on country are in parentheses.

* significant at $10 \%$; ${ }^{*}$ significant at $5 \%$; *** significant at $1 \%$. 